\title{
THE
}

$1-2007$

\section{Assessing Library Skills: A First Step to Information Literacy}

Joanna M. Burkhardt

University of Rhode Island, jburkhardt@uri.edu

Follow this and additional works at: https://digitalcommons.uri.edu/lib_ts_pubs

Part of the Library and Information Science Commons

\section{Citation/Publisher Attribution}

Burkhardt, Joanna M.. "Assessing Library Skills: A First Step to Information Literacy." , (2007). doi: 10.1353/pla.2007.0002.

This Article is brought to you for free and open access by the Technical Services at DigitalCommons@URI. It has been accepted for inclusion in Technical Services Department Faculty Publications by an authorized administrator of DigitalCommons@URI. For more information, please contact digitalcommons-group@uri.edu. 


\section{Project \\ $\mathrm{MUSE}^{\circ}$ \\ Today's Research. Tomorrow's Inspiration.}

\section{Assessing Library Skills: A First Step to Information Literacy}

Burkhardt, Joanna M.

portal: Libraries and the Academy, Volume 7, Number 1, January 2007, pp. 25-49 (Article)

Published by The Johns Hopkins University Press DOI: 10.1353/pla.2007.0002

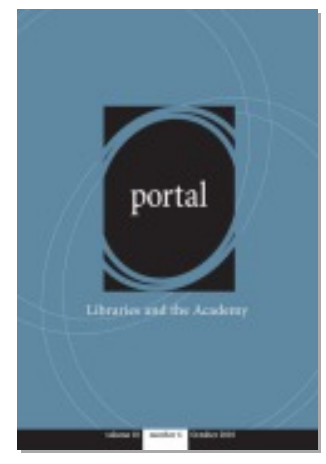

For additional information about this article

http://muse.jhu.edu/journals/pla/summary/v007/7.1burkhardt.html 


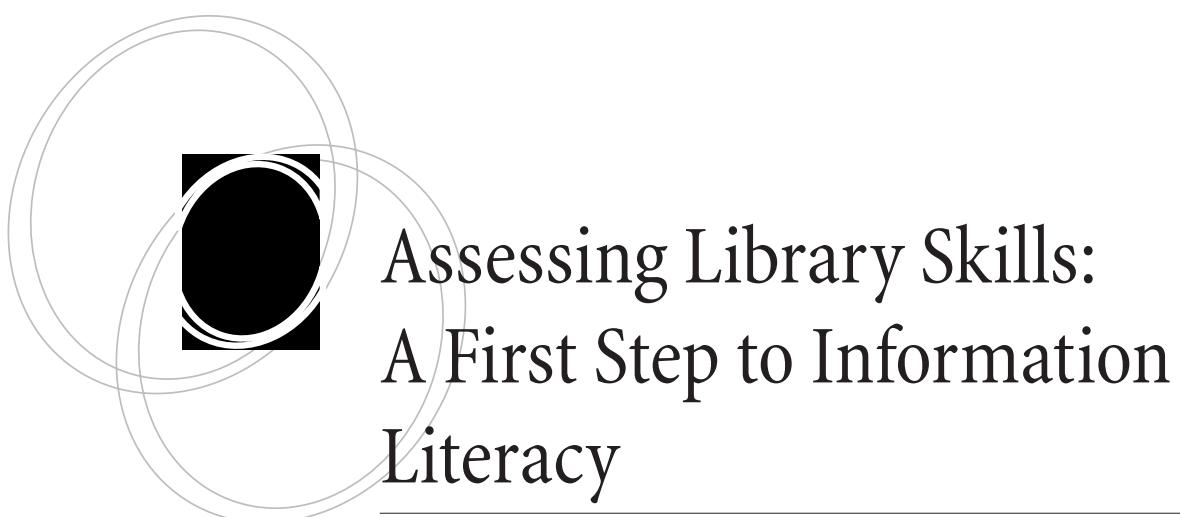

Joanna M. Burkhardt

abstract: As part of the University of Rhode Island Libraries' “Comprehensive Plan for Information Literacy," a three-credit class in the skills and concepts of information literacy was first offered in the fall of 1999. More than 1,000 undergraduate students have taken the class since that time. A pre-test was given at the beginning of each semester, followed up by a post-test at the end. The pre- and post-test results were analyzed to determine: (1) whether students improved their test scores over the course of the semester, (2) which concepts and skills students mastered, and (3) where the course might need revision and/or improvement. Analysis showed that skills were acquired and/or improved overall.

\section{Introduction}

$\mathrm{I}$ n 1998, a University of Rhode Island (URI) Library faculty task force began crafting a comprehensive plan for information literacy for the university. ${ }^{1}$ In addition to traditional bibliographic instruction sessions and the creation of guides and tutorials, a needs assessment indicated that students wanted or needed in-depth instruction that would allow them to learn how to create a research question, identify and use appropriate tools for finding information, evaluate and select information, and apply the selected information to their original question. To address these needs in the comprehensive plan, several methods of instruction were envisioned. One of these methods was to offer one or more for-credit classes in which students could get in-depth instruction in the skills and concepts of information literacy. 


\section{History of LIB 120: Introduction to Information Literacy}

About the time the task force went to work, the library's dean indicated that he would support the creation of credit courses in information literacy. The creation of credit courses was somewhat problematic, as short staffing and heavy workloads allowed little time for new initiatives. Although the idea had appeal to a number of faculty members, no definite proposal appeared until the fall semester of 1998. On a bus ride between meetings at the 1998 American Library Association Annual Conference in Washington, D.C., an outline syllabus was sketched on the back of a program flyer.

From those humble beginnings two undergraduate credit classes emerged-a onecredit "lab" designed to accompany a subject specific course and a three-credit course designed to stand alone. These courses were laid out in detail, approved by the library faculty, and sent through the approval process for new courses at the university. The one-credit lab course (LIB 140, Special Topics) was first offered in conjunction with a business class that declared majors are required to take at URI. The stand alone threecredit class (LIB 120, Introduction to Information Literacy) was offered first as an elective at the Providence campus, where the population of adult learners was most in need of updated skills and information regarding library research in the electronic age.

The following semester, two sections of LIB 120 were offered, one in Providence and one at the main campus in Kingston. Student reactions to the course were positive on both campuses. In fact, many of the students indicated that it was one of the most helpful courses they had ever taken. They recommended the course to their peers and even wrote letters to the dean. The library's Public Services Department agreed to expand the number of sections available as it became possible to do so.

In order to expand enrollment, the consensus was that a plan or strategy was needed. Students in degree programs have many required courses and a limited number of credits earmarked for elective courses. To make the course more visible and attractive to students, it was necessary to provide an incentive for students to enroll in LIB 120. To provide this, the course was proposed to the General Education Committee of the Faculty Senate to be added to the short list of courses that satisfy the general education requirement in English communication. The proposal was accepted. The course now satisfies a general education requirement, making it more attractive to undergraduates.

At about the same time, a presentation was made to the Council of Deans to inform them about the course and its objectives. This advertising strategy also proved successful. The dean of University College was very interested in making the course part of the new Freshman Learning Communities Program at the university. Groups of 25 freshmen were identified and enrolled together in three introductory courses. This allowed new students to get to know a small group of people and to see and interact with them on a daily basis. LIB 120 became one component of the Freshman Learning Communities Curriculum offered each year in the fall semester at the Kingston Campus. For several semesters, the number of sessions offered grew until the library was unable to provide additional instructors.

A third strategy that was employed was advertising the course in general. Flyers about the course were sent to advisors on a regular basis. Flyers were posted in strategic locations during enrollment periods. The course syllabus was on file at the student 
services offices on both campuses. The course outline, learning outcomes and methods, and course content were available on the library Web site. Much to our gratification, students who took LIB 120 recommended the course to others with enthusiasm. Nonlibrary faculty who taught students after they completed LIB 120 commented on the improvement in the quality of student research. These faculty members also encouraged students to take the class. In fact, the voluntary word-of-mouth advertising by students and faculty-coming from peers and respected authority figures on

Much to our gratification, students who took LIB 120 recommended the course to others with enthusiasm. campus - has proved to be one of most valuable methods of encouraging others to take the course.

A final strategy was to adapt the course for distance learning. Students often find time to take a course during the summer months, but their summer location and/or schedule may prohibit them from attending classes. The university encouraged faculty to propose courses that could be offered online. A version of LIB 120 was created to accommodate distance learners and was first offered as a Web-based asynchronous 10-week course during the summer of 2001. Whereas the format and execution of the class were very different in the Web environment, distance students were very pleased to have the course made available to them. They have also been vocal advocates for the class.

This combination of strategies created a demand for the class, and as many as eight sections of the course have run in a single semester. More than 1,000 students have taken LIB 120 during the past five years. Library faculty first taught the course on an overload basis, outside of the regular work requirements. This proved to be inconvenient for many faculty members. In order to increase the number of instructors available to teach LIB 120, the university administration agreed to give the library funding that was equivalent to what they would pay per-course instructors for each section. The library then used the funds to hire additional personnel in the Public Services Department and "released" library faculty from some of their other duties to allow them the time to teach the class. Although this tactic provided enough personnel to staff eight sections of the class, training and supervision of the additional staff in the Public Services Department were time consuming. The department agreed that anything beyond eight sections would require the university to provide additional full-time positions. The library had enough space and equipment to accommodate up to eight sections, but major expansion of the program would require increases. The university administration, therefore, must decide if, when, and how to fund further expansion of the program.

\section{The Course-Content and Pedagogy}

When LIB 120, Introduction to Information Literacy, was created in 1999, there were very few credit classes in information literacy. As a result, the course was created in-house, matching course content to what was then the draft "Association of College and Research Libraries (ACRL) Standards for Information Literacy." The class is offered in a face-toface setting, once, twice, or three times weekly, depending on the section. During the summer session, the course is offered as a Web-based asynchronous 10-week class. 
Instructors for LIB 120 employ a variety of teaching methods to accommodate a variety of learning styles. The course includes group work, oral presentations, and a portfolio final project. The class requires active learning, critical thinking, and application of progressively complex concepts and skills. The course marries practical, transferable skills to theory and concepts of information-its availability, its use, and its ethical problems (such as the digital divide, privacy, plagiarism, and freedom of speech). Students get hands-on experience using the classroom computers in almost every class session. Each class exercise addresses one or more of the "ACRL Standards for Information Literacy." The syllabus covers the following topics: what is information, the research process, the quality of information, monographic information, periodical information, the Internet, information packaging, statistics and experts, and issues of the information age. The final project for the class is a portfolio, of sorts, demonstrating the process of amassing the information needed to write a 10-page term paper. The portfolio includes a bibliography of information selected for inclusion, a bibliography of information examined but rejected, a journal discussing the process of collecting and evaluating each type of information (monographs, journals, Web sites, interviews, and so on), a detailed outline of the paper that would result from the research-including links to the first bibliography to show where the information obtained would apply, transcripts of interviews, and any other items collected that would help tell the story of the research process. The course, including learning objectives, is described in detail at the University of Rhode Island Libraries' Web page. ${ }^{2}$

To get a sense of what library skills the LIB 120 students acquired during the semester, a pre-test was given at the beginning of each semester. This was followed up with a post-test at the end of each semester. These pre- and post-tests target mastery of library skills. Comparing the pre- and post-test results establishes a preliminary benchmark or a first step in the student journey toward information literacy.

The University of Rhode Island Libraries' “Comprehensive Plan for Information Literacy" called for assessment of learning outcomes for LIB 120. As a first step in the assessment process, the pre- and post-test results were analyzed to determine: (1) whether students improved their test scores over the course of the semester, (2) which concepts and skills students mastered (or did not master), and (3) where the course might need revision and/or improvement.

\section{Literature Review}

Assessment of learning outcomes has begun to play a large part in the library literature. A review of the recent literature shows a growing interest in analyzing learning outcomes for information literacy using standardized instruments both at the national and regional levels. Three projects of this kind are described in the literature, although little has been published about the results. Ilene Rockman summarized these national and regional level assessment projects. ${ }^{3}$

The first of the three initiatives is Project SAILS. ${ }^{4}$ This is a project for the standardized programmatic assessment of information literacy skills. The online instrument uses multiple choice options. Lisa O'Connor, Carolyn Radcliff, and Julie Gedeon describe creation of the instrument in detail, and the project is thoroughly discussed and de- 
scribed on the Web site. ${ }^{5}$ To this point, relatively little has been written about the results of applying the instrument.

A second online assessment tool is the Educational Testing Service ICT (Information and Communication Technology) literacy assessment. ${ }^{6}$ The ETS product is an online instrument built on scenario-based task performance. It measures proficiency in the use of both technology and information literacy. The instrument became available for general use in early 2006.

The Bay Area Community College Information Competency Assessment Project is another relatively new measure whose results are available at its Web site but have not yet appeared in the literature. This two-part instrument uses multiple choice, matching, and short-answer questions in part $A$ and performance-based exercises in part B. Results have been analyzed by members of the project and are available at the Web site. ${ }^{7}$

Other sources of information about assessment and learning outcomes as relates to information literacy are available at the division level of the ALA Web site. ${ }^{8}$ ACRL and AASL offer a wealth of material on assessment, including recommended Web sites, best practices, tests and tutorials, and-of course-the national standards for information literacy. The sites offer numerous links to reports about learning outcomes and how they were collected and analyzed by a handful of large and small institutions.

Unfortunately, at the time an assessment instrument was needed for LIB 120 not only were there very few examples of assessment instruments in the library literature but also most of those that existed related to assessment of one-shot bibliographic instruction sessions or integration of information literacy skills in non-library classes and not credit courses. Furthermore, the literature of assessment in libraries consists mostly of case studies, using locally specific instruments to measure outcomes of local interest. Test instruments at the national or even the regional level had not yet been written when assessment of LIB 120 began. Finally, the existing literature has very few longitudinal studies. Most of the literature focuses on preliminary trials of assessment tools rather than long-term results.

Case studies remain the backbone of assessment in libraries. Although not always scientifically rigorous, case studies represent approaches to the problems instruction librarians struggle with on the front lines. Analysis of results at these local levels was done before any standardized regional or national effort was imagined. This kind of report is useful since it captures local trends, innovative ideas, areas of special interest, and institutional or program-specific learning outcomes. Joan Kaplowitz reports on a pre-/ post-test comparison of student learning outcomes for a library instruction program in English 3 classes at UCLA. ${ }^{9}$ Martha Cooney and Lorene Hiris explore the need for information literacy instruction at the graduate level. In their article they discuss integration of information literacy into the graduate business curriculum and use a locally developed checklist for learning outcomes assessment. ${ }^{10}$ Judith Larkin and Harvey Pines write about assessment outcomes for research instruction incorporated into an introductory psychology course at Canisius College. ${ }^{11}$ Again, the assessment measures were locally developed. Heidi Julien and Stuart Boon report on learning outcomes for Canadian academic libraries involved in a three-year study of information literacy instruction. ${ }^{12}$ Success in information literacy and its impact on subsequent educational success was measured and reported in this study. Pre- and post-tests were part of the 
methodology, as were interviews with students-all locally invented. Chris Portmann and Adrienne Roush write about measuring the influence of a one-hour training session on college students' library use and library skill development. ${ }^{13}$ The instrument used for assessing skills was taken from Denise Madland and Carol Hagness (who used it in their own study) and adapted for use at their location. ${ }^{14}$ Smiti Gandhi focuses on assessing the learning outcomes for a five-session model of library instruction at Valencia Community College East Campus. ${ }^{15}$ His model was locally created, as well. Dorothy Anne Warner reviews the Rider University Library instruction program's qualitative assessment project. The information gained from the locally developed assessment instruments was linked to the ACRL "Information Literacy Standards" to determine the effects and effectiveness of the instruction. ${ }^{16}$ Janice Webster and Loretta Reilly report on effectiveness and satisfaction levels for students, faculty, and librarians involved in subject-specific library instruction at Oregon State University. ${ }^{17}$ Loanne Snavely and Carol Wright report on the use of research portfolios as authentic assessment tools. ${ }^{18}$ Kathleen Dunn discusses assessment at California State University using scenarios representing real life issues or problems for testing. ${ }^{19}$ Linda Carder, Patricia Willingham, and David Bibb report outcomes for a case-based, problem-based approach to assessing student ability to identify their information needs. ${ }^{20}$

These selected articles represent only a portion of the literature devoted to case studies involving assessment of learning outcomes for information literacy and/or library instruction. They demonstrate that many institutions created their own assessment instruments in the absence of any national or regional instrument, applied those instruments, and reported on their results. As with so many of the studies described

As this study covers a five-year period, it examines results over a much longer time period than most of the other case studies in the literature. above, the creation of a credit course in information literacy at URI required the creation of a local test instrument to satisfy the local questions about student learning outcomes and course-related successes and failures. The results obtained reflect the student learning for an entire semester of weekly exposure to library skills. As this study covers a five-year period, it examines results over a much longer

time period than most of the other case studies in the literature.

This case study will add to the knowledge base regarding assessment of library skills. It is one of a very few studies that provides information and analysis of student learning outcomes for a credit-bearing, stand-alone course in information literacy. Analysis of the results will inform instructors about the level of success URI has had in conveying the introductory concepts and skills of information literacy to its students. It is hoped that other institutions offering credit-bearing courses in information literacy will document the learning outcomes for their courses in the literature in the near future.

\section{Case Study}

The University of Rhode Island is a medium-size institution granting degrees, from the baccalaureate level to the doctoral level. The university has three campuses: the main 
campus in Kingston, the Graduate School of Oceanography in Narragansett, and the urban campus in Providence. The university enrolls approximately 13,000 FTE students. The library at URI is its own college, and librarians are faculty members. In 1998, during a library self-study, information literacy instruction was identified as a topic needing exploration. A small task force was established to look into this and report back to the entire library staff, particularly to the library administration.

Anecdotal reports from the librarians staffing the URI reference desk and those teaching bibliographic instruction sessions showed that there was a growing demand from both students and faculty for more thorough and detailed library instruction. This stemmed from the large number of online databases available to students, the complex nature of searches, and the poor quality of the sources being used in writing term papers (driven by the limited ability of students to evaluate the quality of the information found on the Internet). The professional literature at that time showed that the demand for more instruction was not limited to the campuses of URI; indeed, it was clear that the problems were global and of increasing concern to educators everywhere.

The URI Libraries' task force created a plan for information literacy for URI. The plan was researched, written, and eventually approved by the library faculty in $2000 .{ }^{21}$ Two credit-bearing courses were created as a first step toward addressing the unmet needs listed above. LIB 120, Introduction to Information literacy, a three-credit course that satisfies a general education requirement within English communication, has been a major focus of the implementation of the comprehensive plan for the past five years. As a means of assessing some student learning outcomes for the class, a pre- and post-test were given in order to assess the mastery of library skills used in the class.

\section{History of the Pre- and Post-Test}

The pre- / post-test for LIB 120 was created in 1999 to obtain some preliminary data on what library skills students learned during the course. The test was created as an in-house feedback instrument to inform instructors about what skills were successfully mastered and what skills might need to be taught differently or given a different emphasis. The test also measured, to some extent, the acquisition of basic information literacy skills and concepts. Test questions were based on the concepts and skills presented during the semester in lectures, in-class exercises, homework assignments, and the portfolio project. Questions tested the skills needed to achieve the eight stated student learning objectives for the class:

1. Understand the organization of information systems

2. Recognize and articulate a research problem

3. Develop appropriate and effective search strategies

4. Select and use information retrieval tools

5. Locate and retrieve information sources

6. Analyze and critically evaluate information

7. Organize and synthesize information

8. Use and apply information effectively 
For the first five years that the course was offered, the same test was given both at the beginning and at the end of the semester. Students were not informed that the two tests were identical. As increasing numbers of sections of the course were offered, each instructor determined individually whether or not they wished to administer the pre- and post-test.

In the first years of the new millennium, pre- and post-tests were given and collected, but the time needed to prepare for and teach multiple sections of the class, in addition to the other assigned duties of the faculty librarians, left no time for the analysis of the results of the tests. Assessment and learning outcomes became more and more prominent topics in the literature of higher education during these years, along with general education reform and new standards by accrediting agencies that included requirements specific to information literacy. These changes reflected a growing demand for educational institutions to show that they achieved expected and desired results with the programs and classes offered to students. Analysis of the data from the preand post-tests was an obvious first step to inform and validate our efforts to achieve appropriate student learning outcomes in information literacy. In the fall semester of 2005, this analysis was undertaken.

The pre-/ post-test consisted of two parts. The first part collected information about the individuals and their comfort level with various tools used in library research. The second part tested basic competency in the evaluation, selection, and use of tools in library research, including the Internet. Students who took the test were given the pretest on the first day of class. They took the post-test on the last day of class or during the final exam time slot. A copy of the test instrument appears in the appendix.

\section{Methodology}

As was previously stated, instructors of sections of LIB 120 were encouraged, but not required, to give the pre- and post-test. Slightly less than 32 percent of the total enrollment (274 students) took the LIB 120 pre-test (several instructors opted to give only the pre-test). Twenty percent (172 students) took the post-test. Test answers were tabulated and analyzed using SPSS 13.0.

The student comfort level with individual tools such as the online catalog, periodical indexes, and computers was rated. A pre-test "total comfort level" score was also tabulated for correlation with final pre-test total scores. In the second part of the test, questions relating to information tools and their use were asked. Results from the pre-test were compared with results from the post-test, including total score, a question-by-question comparison, and correlation of total score with total comfort level. By using these comparisons, it was possible to determine whether students improved their scores by taking the course and what specific skills and concepts related to information literacy were mastered. The results were also used to identify areas in which revision of the course content might be in order. 


\section{Overall Results}

The pre-test mean score was 13.88 (median 14, standard deviation 3.61) (see figure 1).

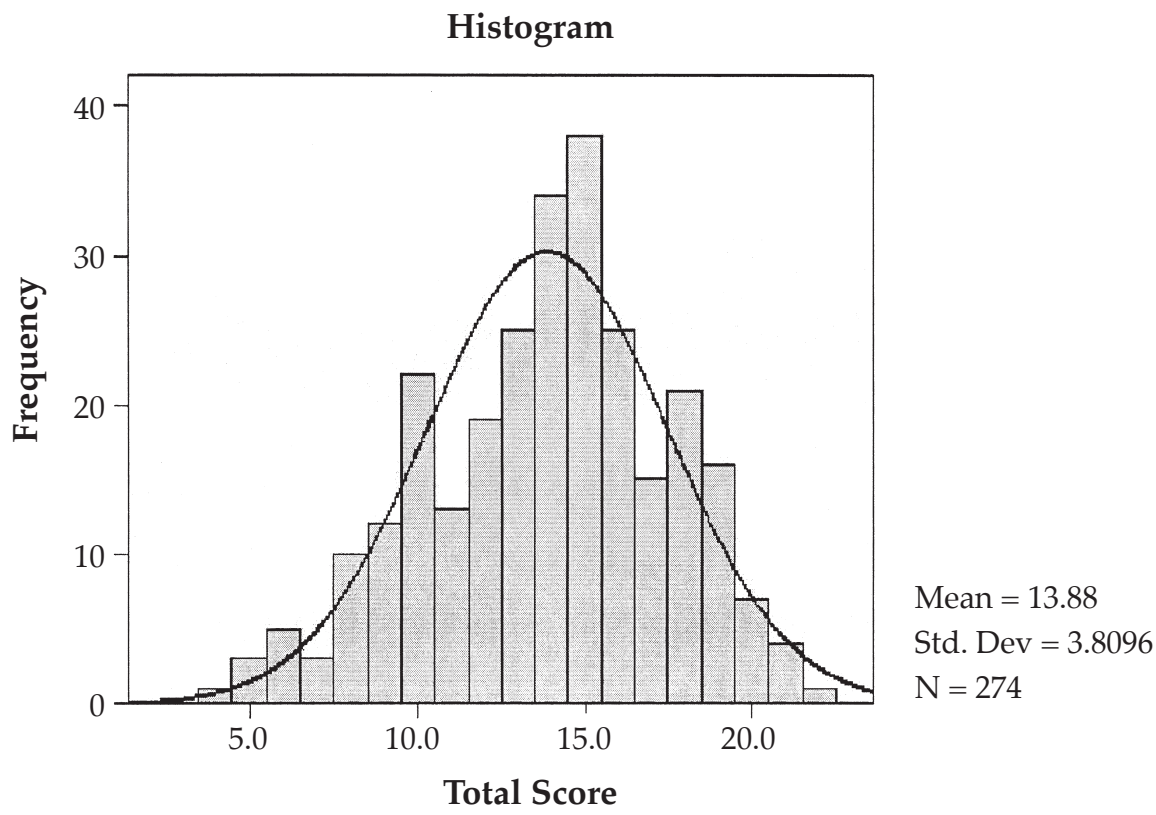

Figure 1. Total Score for Pre-Test

The post-test mean score rose to 17 points (median 17, standard deviation 3.19) (see figure 2).

\section{Histogram}

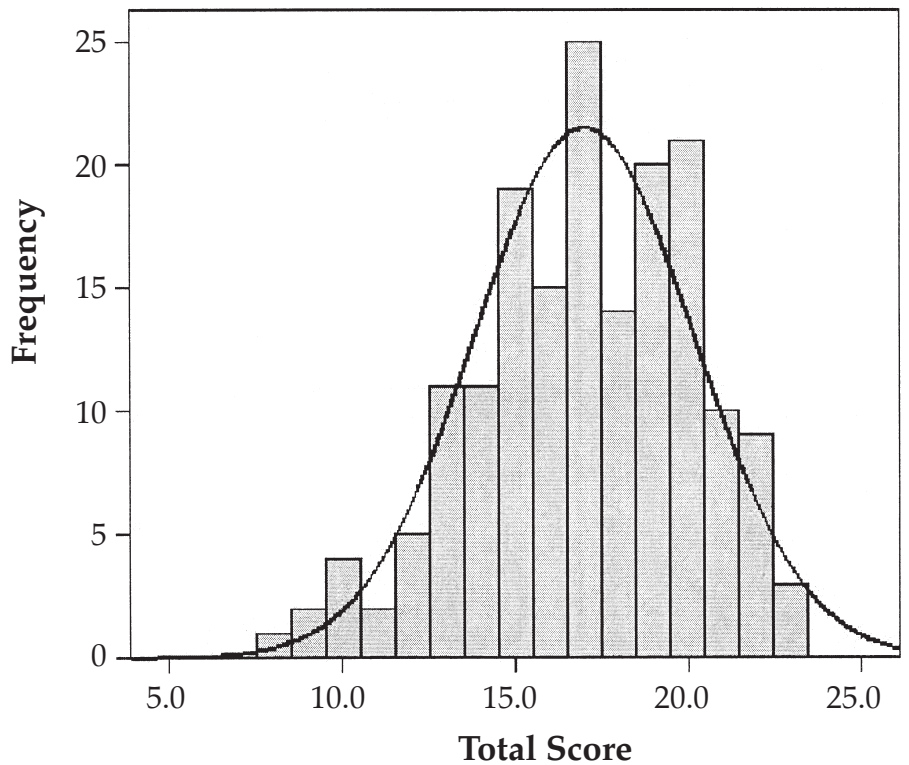

Mean $=13.88$

Std. Dev $=3.8096$

$\mathrm{N}=274$

Figure 2. Total Score for Pre-Test 
The total scores for pre- and post-tests were then compared using a dependent t-test. The result showed that there was a small but significant correlation between the two scores, using Pearson's $r$ and a two-tailed significance value. On average, participants performed significantly better on the post-test $(\mathrm{M}=17, \mathrm{SE}=.285)$ than they did on the pre-test $(\mathrm{M}=14.17, \mathrm{SE}=.244, \mathrm{t}(171)=-7.207, \mathrm{p}<.05, \mathrm{r}=.48)$. The result was statistically significant; the effect size was between medium and large (see figure 3 ).

\section{T-Test Comparing Pre-Test and Post-Test Total Scores}

Paired Samples Correlations

\begin{tabular}{|ll|c|c|c|}
\hline & $\mathrm{N}$ & Correlation & Sig. \\
\hline $\begin{array}{l}\text { Pair } \\
1\end{array} \quad \begin{array}{l}\text { Pre-test total score and } \\
\text { Post-test total score }\end{array}$ & 172 & -.101 & .187 \\
\hline
\end{tabular}

\section{Paired Samples Statistics}

\begin{tabular}{|ll|c|c|c|c|}
\hline & Mean & N & Std. Deviation & $\begin{array}{c}\text { Std. Error } \\
\text { Mean }\end{array}$ \\
\hline $\begin{array}{ll}\text { Pair } \\
1\end{array}$ & $\begin{array}{l}\text { Pre-test total score } \\
\text { Post-test total score }\end{array}$ & 14.1686 & 172 & 3.73392 & .28471 \\
\end{tabular}

Figure 3. T-Test Comparing Pre-Test And Post-Test Scores

\section{Individual Question Results}

Of particular interest was whether students learned how to select appropriate tools for the type of information they needed. For example, question 6 asked what would be the appropriate tool to use to find background information on a topic. The possible answers were the online catalog, the Internet, an encyclopedia, or the Reader's Guide to Periodical Literature. The correct answer was encyclopedia. On the pre-test, 47.5 percent of those who answered gave encyclopedia as their answer. On the post-test, 62.1 percent gave the same answer. The number of people who gave the correct answer on the post-test increased by almost 15 percent. In conducting a t-test comparing the pre- and post-test results for this question, we found that, on average, students answered question 6 correctly more often on the post-test $(M=2.74$, S.E. $=.068)$ than on the pre-test $(M=2.40$, S.E. $=.089, \mathrm{t}(159)=-3.029, \mathrm{p}<.05 . \mathrm{r}=.234)$ (see figure 4$)$.

Question 8 asked students to select a definition for a periodical index from the following choices: something you use to identify journal articles on a topic, a list of journals in the library, what you use to find books on a topic, or the table of contents for a magazine.

On the pre-test, 44.4 percent answered correctly. On the post-test 46.1 percent answered correctly. This small gain in the number of people who were able to answer the question correctly was disappointing because it indicated that after a semester of 


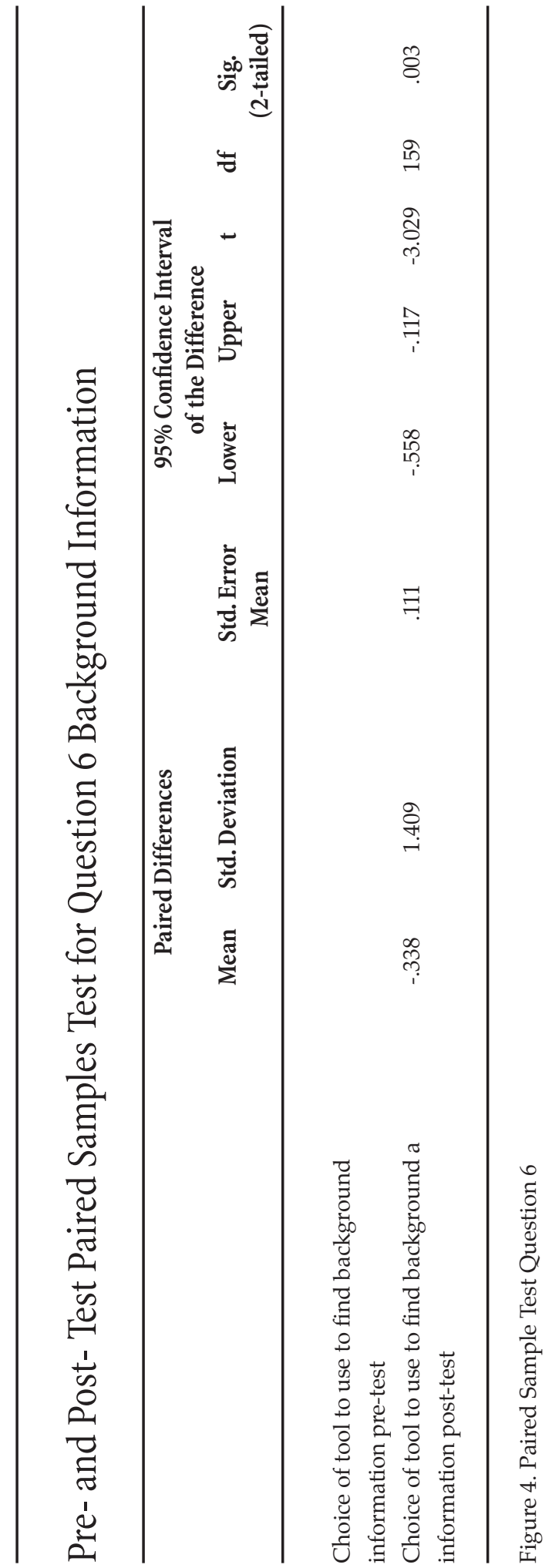


instruction, fewer than 50 percent of the people who took the class could select a definition for periodical index from a multiple choice list. In this case, the t-test showed that, on average, students taking the post-test $(\mathrm{M}=1.9$, S.E. $=.075)$ were no more likely to answer this question correctly than were those taking the pre-test $(\mathrm{M}=1.9$, S.E. $=.060$, $\mathrm{t}(166)=-1.125, \mathrm{p}>.05, \mathrm{r}=.089)$ (see figure 5).

Two journal citations were given in question 13. Students were asked to identify the title of the journal in the citations. In the pre-test, 52.4 percent of the students identified one or both journal titles. In the post-test, only 48 percent of the students answered the question correctly. A t-test showed that the difference in the scores was significant, indicating that students were less likely to answer correctly on the post-test than they were on the pre-test. Clearly this is an area that requires more emphasis or a new approach (see figure 6).

Search building is an important part of finding specific information. Understanding Boolean operators and how they work is critical in search building. In question 12 , students were asked to determine what journal article topic would fit the Boolean search "cats AND (dogs OR ducks)." Although the percentage of students answering correctly rose by approximately 14 percent (from 37.1 percent to 54.3 percent), the total number of students who answered the question correctly after a semester of instruction was disappointingly low. The t-test comparing pre-test and post-test answers for this question indicated that the difference was statistically significant with a very small possibility that the change was the result of chance alone (see figure 7).

Overall results for each individual question, total score, and total comfort level are given in figure 8 . Scores improved in almost all cases.

\section{Comfort Level Results}

Comfort level scores increased from the pre-test to the post-test. Comfort levels for the pre-test and the post-test were compared to each other. Using a dependent t-test, it was found that, on average, students reported a significantly higher comfort level with computers and the related tools and technology in the post-test $(\mathrm{M}=6.96, \mathrm{SE}=.162)$

Making students comfortable with the tools and technology required for research had a positive impact on their post-test scores. than they reported in the pre-test $(\mathrm{M}=4.52$, $\mathrm{SE}=.206), \mathrm{t}(135)=-9.571, \mathrm{p}<.05, \mathrm{r}=.206)$ (see figure 9).

A correlation analysis shows that there was a significant correlation between comfort level total score and test total score. The correlation was significant for both the pre-test and the post-test results. By using computers in almost every class and by explaining and allowing hands-on use of many information tools, students became more familiar and comfortable with computers and related tools. Making students comfortable with the tools and technology required for research had a positive impact on their post-test scores (see figure 10). 


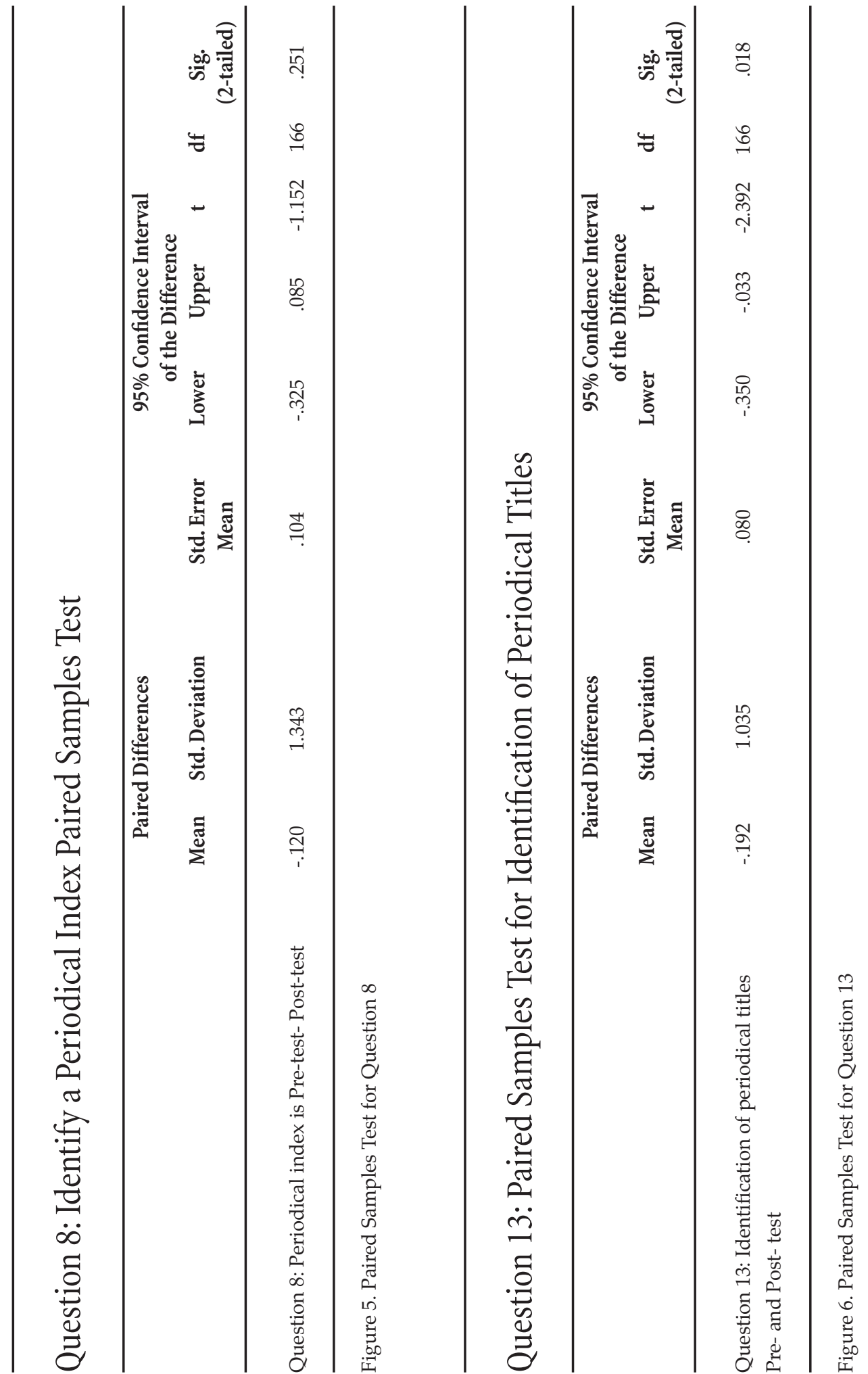




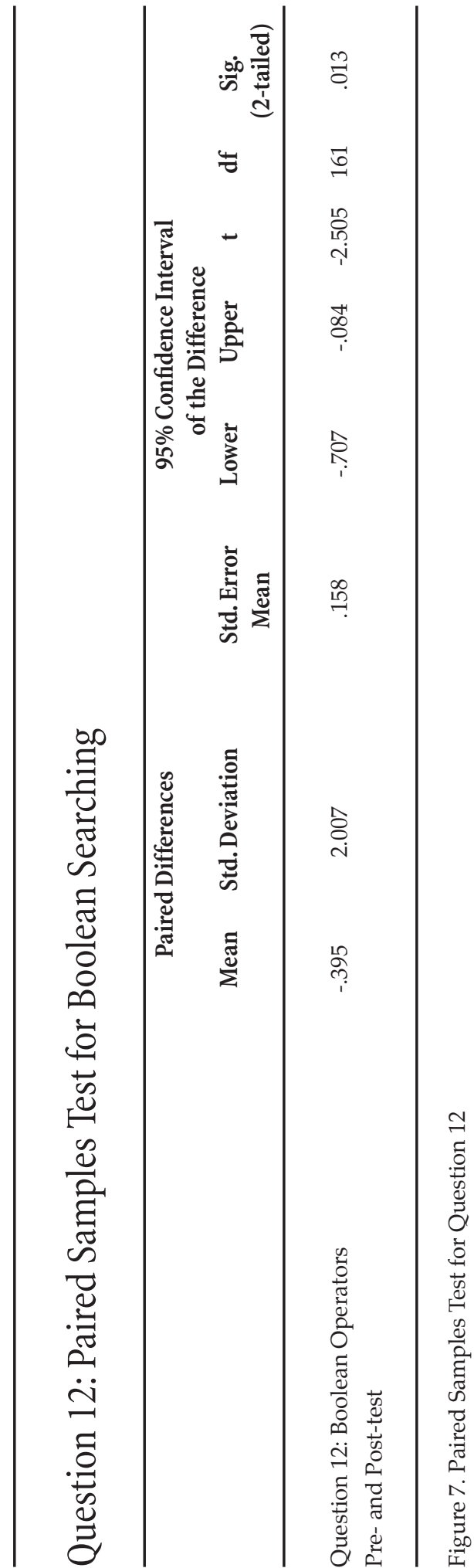




\section{Pre- and Post-Test \% of Students Selecting the Correct Answer}

\begin{tabular}{|c|c|c|c|}
\hline Question number & Pre-Test \% & Post-Test \% & $\%$ Change \\
\hline 5 & 81.4 & 95.3 & 13.9 \\
\hline $5 b$ & 48.0 & 90.7 & 42.7 \\
\hline 6 & 47.3 & 62.1 & 14.8 \\
\hline 7 & 68.8 & 93.0 & 24.2 \\
\hline 8 & 44.4 & 46.1 & 1.7 \\
\hline 9 & 93.1 & 97.7 & 4.6 \\
\hline $10 a$ & 58.0 & 84.3 & 26.3 \\
\hline $10 \mathrm{~b}$ & 65.7 & 75.6 & 9.9 \\
\hline $10 \mathrm{c}$ & 34.7 & 62.2 & 27.5 \\
\hline $10 \mathrm{~d}$ & 79.2 & 90.1 & 10.9 \\
\hline $10 \mathrm{e}$ & 32.5 & 43.0 & 10.5 \\
\hline 11 & 43.7 & 69.6 & 25.9 \\
\hline 12 & 37.1 & 54.3 & 17.2 \\
\hline 13 & 52.4 & 48.0 & -4.4 \\
\hline 14 & 85.4 & 91.9 & 6.5 \\
\hline 15 & 83.9 & 87.7 & 3.8 \\
\hline 16 & 90.4 & 92.4 & 2.0 \\
\hline 17 & 25.6 & 78.6 & 53 \\
\hline $18 \mathrm{a}$ & 66.3 & 91.2 & 24.9 \\
\hline $18 \mathrm{~b}$ & 63.9 & 71.2 & 7.3 \\
\hline $18 \mathrm{c}$ & 85.8 & 81.2 & -4.6 \\
\hline $18 \mathrm{~d}$ & 57.7 & 71.2 & 13.5 \\
\hline $18 \mathrm{e}$ & 71.5 & 85.3 & 13.8 \\
\hline Total Score & 59.0 & 70.8 & 11.8 \\
\hline Comfort Level & 5.06 & 6.93 & 1.87 \\
\hline
\end{tabular}

Figure 8. 


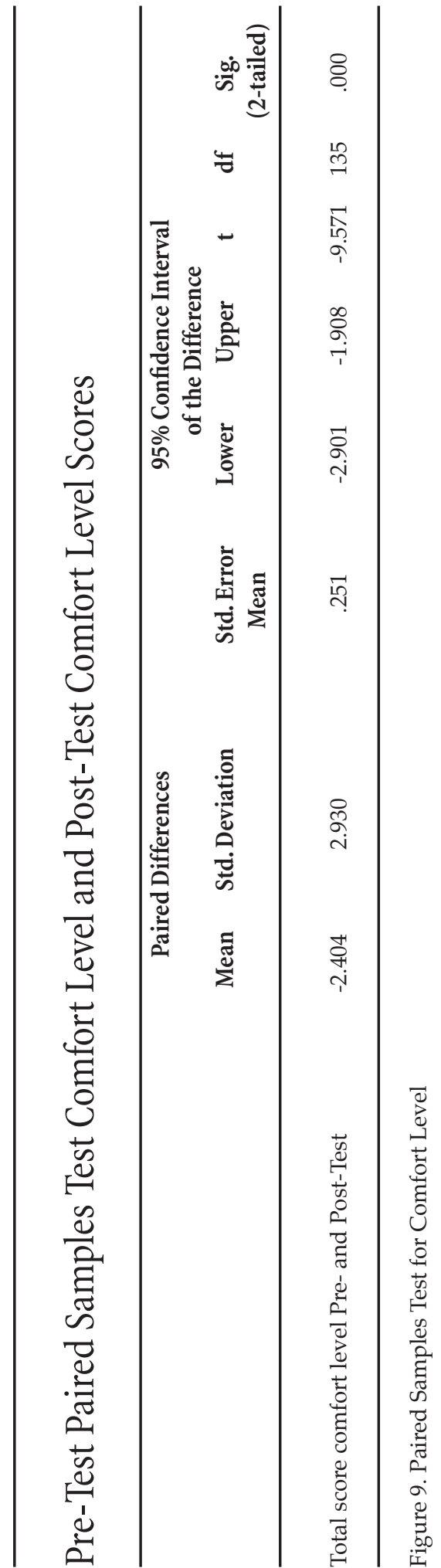




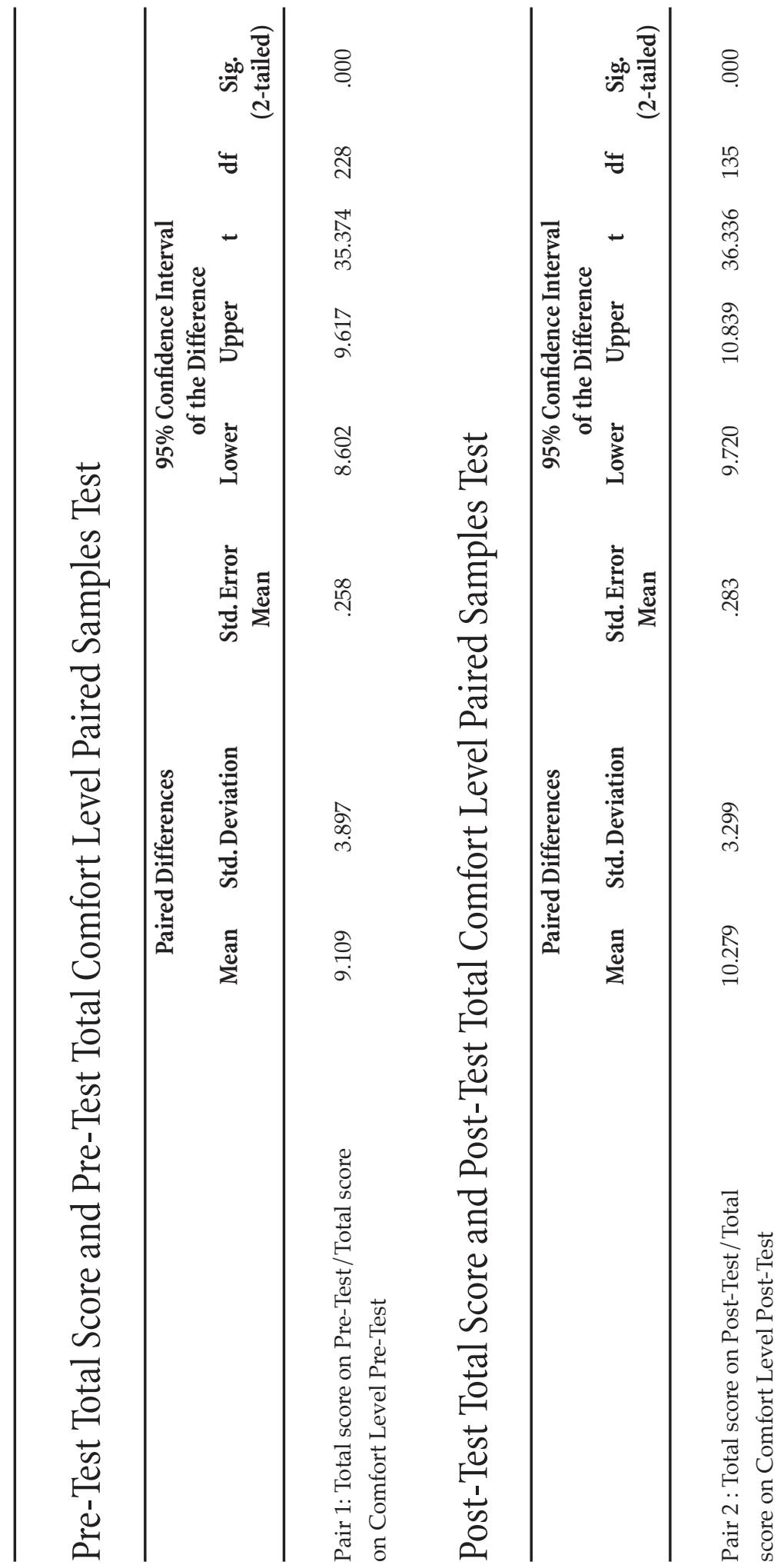




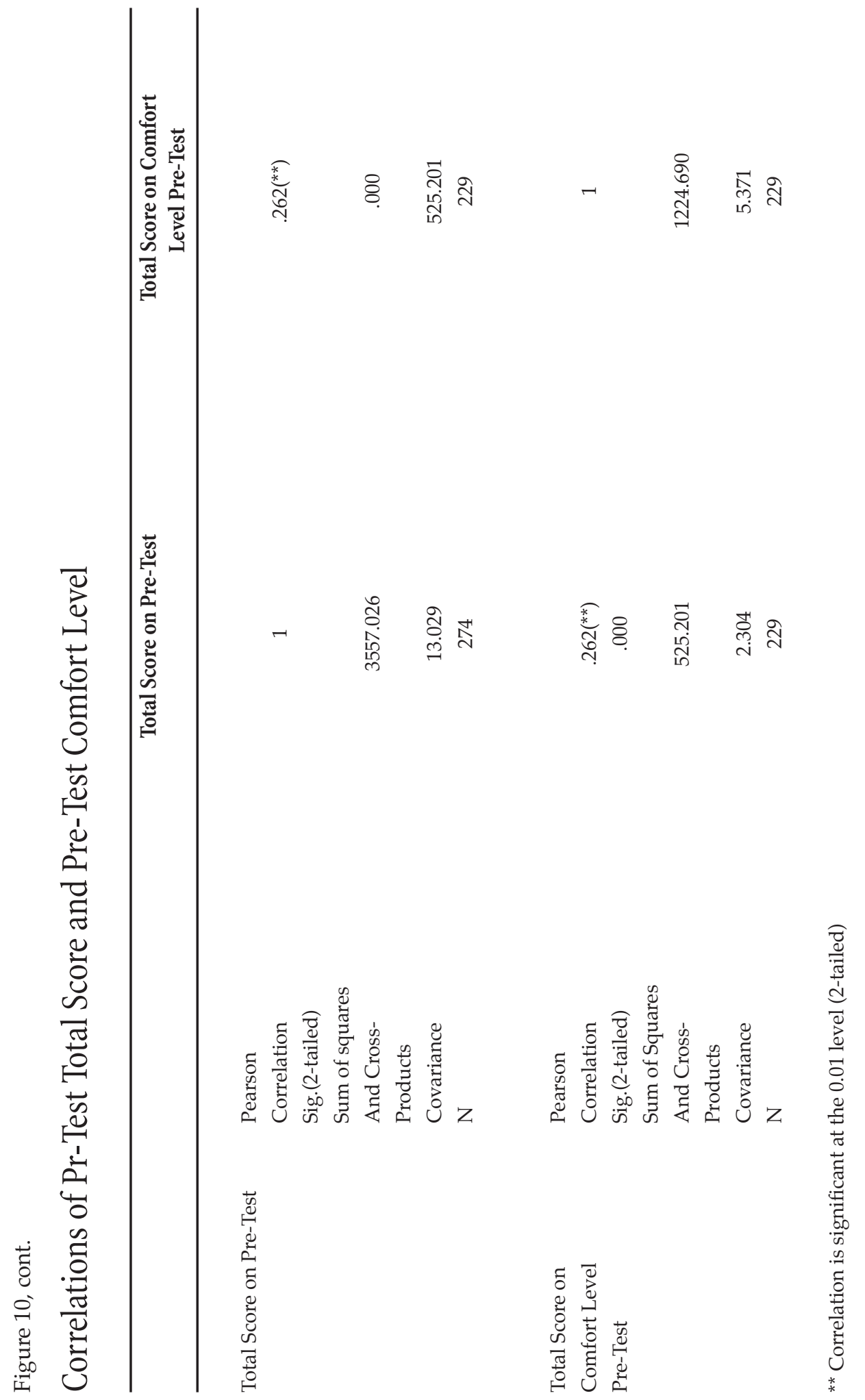




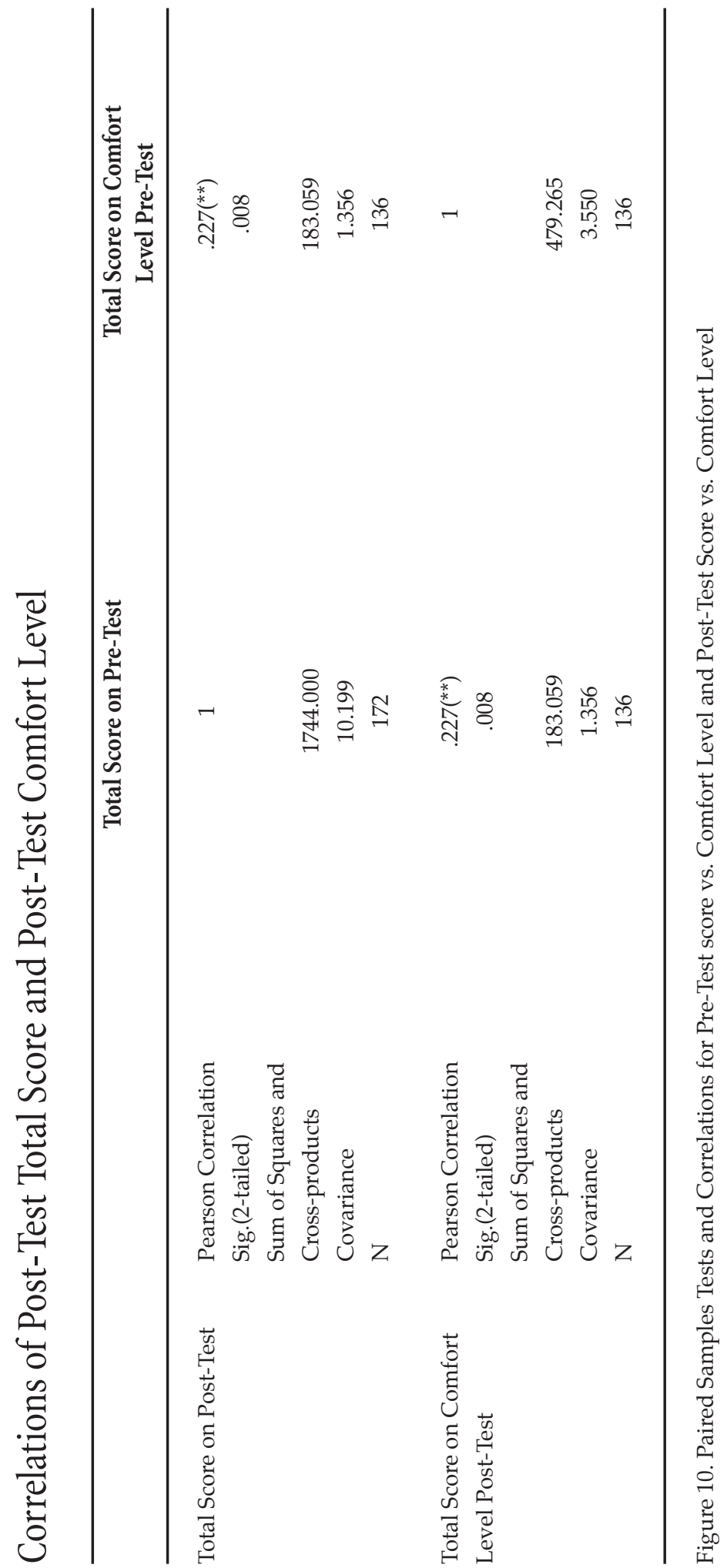




\section{Conclusions Regarding Learning Outcomes From Assessment of LIB 120}

As a result of the analysis of the pre- and post-test scores, baseline information about student learning outcomes for library skills mastery was obtained. The improvement in the scores on individual questions proved to be statistically significant almost across the board. The two questions in which no improvement was observed stand out conspicuously. In this analysis, clear evidence was obtained that the topics addressed by these two questions need more emphasis and/or new approaches. For example, most students did not improve in their ability to name and / or identify parts of a citation. In review of this item with the LIB 120 instructors group, it was found that most instructors discussed this topic only once, early in the course of the semester. As a result of the test analysis and discussion, a new module for identifying the components of a citation is under construction. More emphasis will be given to the topic, and instructors will be encouraged to review the material in each appropriate segment of the class.

In general terms, the statistical analysis of the pre- and post-test scores showed that library skills were improved and strengthened by taking the LIB 120 class. As familiarity and comfort levels with technology and associated research tools increased, total scores also increased. As a first-pass analysis of learning outcomes, this study was useful and informative. Results of this study will help instructors to deliver the course content more effectively. The results of pre- and post-tests given after 2005 will be tabulated, analyzed, and discussed with LIB 120 instructors on an annual basis to ensure that feedback about student learning outcomes is current and also to more closely track the results of changes made to the course.

LIB 120 instructors feel that it is important to compare our homegrown assessment instrument to a test instrument that has been created and used on a regional or national level. The university is also encouraging the use of assessment instruments that are used by other institutions across the nation for the sake of comparability. Therefore, as a second step in moving the assessment plan forward, students taking LIB 120 during the fall semester of 2006 will take a modified version of the Bay Area Community College information competency assessment exam as the final exam for the course. This instrument goes beyond testing the mastery of library skills to measure the mastery of the introductory concepts and skills of information literacy. Using this instrument will allow URI Libraries' faculty to assess if and how well LIB 120 students have attained a basic level of information literacy. It will also allow results to be compared with outcomes from other institutions using the same instrument.

In the larger context, the URI experience is somewhat unique. Credit courses in information literacy are few. Although anecdotal reports from both URI students and non-library faculty as well as the results of our assessment indicate that LIB 120 is successful in improving research skills and in improving the final product for courses requiring research papers and presentations, teaching the course is labor intensive and fairly expensive when considered on a per student basis. However, any institution could meet the need for information literacy using the URI program as a model. Institutions with the financial resources to do so could circumvent the creative funding strategy used at URI and perhaps create a program that reaches every student on campus.

At URI, the analysis of the pre- and post-test results and the anecdotal evidence from students and non-library faculty provided clear evidence that LIB 120 offers valuable 
as well as practical content and does help students to become information literate. As the results of national-level testing by ETS, the Bay Area Community Colleges Information Competency Assessment Project, and Project SAILS build, it may become clear that instruction in information literacy must go beyond the 50-minute, one-shot instruction session in the library. In that event, credit courses like LIB 120 may be helpful in providing a model with a record of success that other institutions can emulate.

\section{Acknowledgements}

I would like to acknowledge the generosity of the University of Rhode Island for the sabbatical granting me the time to pursue this research and to the University of Rhode Island Research Office for their "Career Enhancement Grant" that allowed me to attend the ARL Service Quality Evaluation Academy in Austin, Texas, in May of 2005.

Joanna M. Burkhardt is head librarian, University of Rhode Island-Providence Campus Libraries, Providence, RI; she may be contacted via e-mail at: jburkhardt@uri.edu.

\section{Appendix}

\section{LIB 120 Introduction to Information Literacy Skills Survey}

Students come to college with different levels of understanding of the research process and different amounts of experience doing research. The purpose of this survey is to gauge the level of experience of the class as a whole in doing research. The survey is anonymous, so don't worry about whether you get some answers wrong-just answer the questions to the best of your ability.

1. What level of school have you completed?

High School

Some college

Completed the following degree (include dates)

2. What type of library are you most familiar with?

Public

School

College/University

Other (please specify)

3. How long has it been since you've used a library?

One week or less

More than a week but less than a month

More than a month but less than a year

More than a year

Do not remember 
4. Are you comfortable using the following library materials and computer applications? (Please circle yes or no.)

$\begin{array}{lll}\text { Online library catalog } & \text { yes } & \text { no } \\ \text { CD-ROM databases } & \text { yes } & \text { no } \\ \text { Periodical indexes } & \text { yes } & \text { no } \\ \text { Reference collection } & \text { yes } & \text { no } \\ \text { World Wide Web } & \text { yes } & \text { no } \\ \text { Listservs } & \text { yes } & \text { no } \\ \text { Computers } & \text { yes } & \text { no } \\ \text { E-mail } & \text { yes } & \text { no } \\ \text { Power Point } & \text { yes } & \text { no }\end{array}$

5. To find a book in the URI library on asteroids, which library tool would you use?

The HELIN library catalog

Yahoo!

The Reader's Guide to Periodical Literature

The World Book Encyclopedia

6. You've successfully identified a book on asteroids owned by the URI library. What is the most important piece of information you need to locate the book in the library?

7. Which of the following information tools is the best choice for locating basic background information on a topic?

The Internet

The Readers Guide to Periodical Literature

An encyclopedia

The HELIN library catalog

8. An abstract of a journal article is:

A summary of the article

The theory underlying the subject matter of the article

An illustration graphically depicting the contents of the article

The actual article in print

9. A periodical index is:

A list of all the periodicals in the library

The table of contents for a magazine

What you use to identify journal articles on a topic

A list of books by subject

10. Which of the following can you locate using the library catalog? (Select all that apply.)

Books

Videos

Magazine articles 
CDs
Journals
Individual poems

11. Your professor has asked you to find an article on the AIDS epidemic in Africa in a popular magazine such as Time or Newsweek. Which of the following sources would be the best choices for finding such an article?

The Reader's Guide to Periodical Literature

The HELIN library catalog

The web site of the Joint United Nations Programme on HIV / AIDS

The Encyclopedia of AIDS

12. A student studying animal behavior enters the following search statement into a database: "cats AND (dogs OR ducks)." Which of the following articles is she most likely to find?

An article on possible health problems of pet cats

An article on how to groom your dog

An article on using dogs in duck hunting

An article on helping your cat adjust to a new puppy

13. Please circle the title of the periodical in the citations below.

a) Dolan, Brian P. "Representing novelty: Charles Babbidge, Charles Lyell, and experiments in early Victorian geology." History of Science volume 36(3), Sept. 1998, p. 299(29).

b) Close encounters. B. Berman. Il. Discovery. V. 19 no. 4, p. 38 Ap '98.

14. The Web site http://plants.usda.gov/plantprof/plants/index.html is probably maintained by:

A government agency

A school, college or university

An organization

A company

15. A "url" is" (Select all that apply)

A number used to find an item on the library's shelves

The address of a World Wide Web site

A Uniform Resource Locator

A Universal Resource Limitation

16. To search the library catalog by author for books by Robert Frost, how would you enter the search?

Robert Frost

Frost Robert

17. Information about a journal article that includes the author, title, volume number, and page number is called the:

Index

Catalog Record 


\section{Bibliography \\ Citation}

18. Which of the following are examples of periodicals? (Select all that apply.)

Journals

Newspapers

Books

Newsletters

Magazines

\section{Notes}

1. University of Rhode Island, University Libraries, "Library 120: Introduction to Information Literacy," University of Rhode Island, http: / / www.uri.edu/library/lib120/ (accessed October 25, 2006).

2. University of Rhode Island, University Libraries Instruction Services, "Comprehensive Plan for Information Literacy," University of Rhode Island, http: / / www.uri.edu / library / instruction_services/infolitplan.html (accessed October 25, 2006).

3. Ilene Rockman, "Information and Communication Technology Literacy: New Assessments for Higher Education," College and Research Libraries News 66, 8 (2005): 587-9.

4. Project SAILS: Standardized Assessment of Information Literacy Skills, Kent State University, www.projectsails.org (accessed October 25, 2006).

5. Lisa G. O'Connor, Carolyn J. Radcliff, and Julie A. Gedeon, "Applying Systems Design and Item Response Theory to the Problem of Measuring Information Literacy Skills," College and Research Libraries 63, 6 (2002): 528-43.

6. Educational Testing Service, "ETS ITC Literacy Assessment Overview," Educational Testing Service, http:/ / www.ets.org/ portal/site/ ets/menuitem.1488512ecfd5b8849a77b13bc3921509/ ?vgnextoid=fde9af5e44df4010VgnVCM10000022f95190RCRD\&vgnextchannel=69d246f167 4f4010VgnVCM10000022f95190RCRD (accessed October 25, 2006).

7. Bay Area Community Colleges, "Bay Area Community Colleges Information Competency Assessment Project," Bay Area Community Colleges, www.topsy.org/ICAP/ICAProject. html (accessed October 25, 2006).

8. American Library Association, "Divisions," American Library Association, http:/ / www. ala.org/ala/ourassociation/divisions/divisions.htm (accessed October 25, 2006).

9. Joan Kaplowitz, "A Pre- and Post-Test Evaluation of the UCLA English 3 Library Instruction Program at UCLA," Research Strategies 4, 1 (Winter 1986): 11-7.

10. Martha Cooney and Lorene Hiris, "Integrating Information Literacy and Its Assessment into a Business Course: A Collaborative Framework," Research Strategies 19, 3 / 4 (2003): 213-32.

11. Judith E. Larkin and Harvey A. Pines, "Developing Information Literacy and Research Skills in Introductory Psychology: A Case Study," Journal of Academic Librarianship 31, 1 (2005): 40-5.

12. Heidi Julien and Stuart Boon, "Assessing Instructional Outcomes in Canadian Academic Libraries," Library and Information Science Research 26, 2 (Spring 2004): 121-39.

13. Chris A. Portmann and Adrienne Julius Roush, "Assessing the Effects of Library Instruction," Journal of Academic Librarianship 30, 6 (2004): 461-5.

14. Denise Madland and Carol Hagness, "The Case of Kelly" in Designs for Active Learning: A Sourcebook of Classroom Strategies for Information Education, ed. Gail Gradowski, Loanne Snavely, and Paula Dempsey (Chicago: Association of College \& Research Libraries, 1998): $146-8$. 
15. Smiti Gandhi, "Faculty-Librarian Collaboration to Assess the Effectiveness of a FiveSession Library Instruction Model," Community and Junior College Libraries 12, 4 (2004): $15-48$.

16. Dorothy Anne Warner, "Programmatic Assessment: Turning Process into Practice by Teaching for Learning," Journal of Academic Librarianship 29, 3 (2003): 169-76.

17. Janet Webster and Loretta Rielly, "A Library Instruction Case Study: Measuring Success From Multiple Perspectives," Research Strategies 19, 1 (2003): 16-32.

18. Loanne L. Snavely and Carol A. Wright, "Research Portfolio Use in Undergraduate Honors Education: Assessment Tool and Model for Future Work," Journal of Academic Librarianship 29, 5 (2003): 298-303.

19. Kathleen Dunn, "Assessing Information Literacy Skills in the California State University: A Progress Report," Journal of Academic Librarianship 28, 1/ 2 (2002): 26-35.

20. Linda Carder, Patricia Willingham, and David Bibb, "Case-Based, Problem-Based Learning: Information Literacy for the Real World," Research Strategies 18, 3 (2001): 181-90.

21. University of Rhode Island University Libraries, "Instruction Section: Plan for Information Literacy at the University of Rhode Island," University of Rhode Island University Libraries, http:/ / www.uri.edu/library/instruction_services/infolitplan.html (accessed October 25, 2006). 